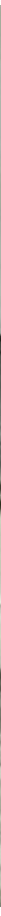

The (French) origins and development of international independent Art on display at the Musée du Jeu de Paume in 1937

As origens (francesas) e o desenvolvimento da arte internacional independente na exposição do Museu Jeu de Paume em 1937

Dra. Kate Kangaslahti

Como citar:

KANGASLAHTI, K. The (French) origins and development of international independent Art on display at the Musée du Jeu de Paume in 1937, MODOS. Revista de História da Arte. Campinas, v. 2, n.2, p. 09-31, mai. 2018. Disponivel em: <http://www.publionline.iar.unicamp.br/index.php/mod/article/view/10 67>; DOI: https://doi.org/10.24978/mod.v2i2.1067

Imagem: Photograph of salle XIV, "Origines et développement de l'art international indépendant" at the Musée du Jeu de Paume, Paris 1937, showing paintings by Joan Miró and sculptures by (left to right) Naum Gabo, Julio González, and Antoine Pevsner. Reproduced in Hommage à Yvonne Zervos. Paris: Tournon, 1970, n.p. (Author's own). 


\title{
The (French) origins and development of international independent Art on display at the Musée du Jeu de Paume in 1937
}

\author{
As origens (francesas) e o desenvolvimento da arte internacional \\ independente na exposição do Museu Jeu de Paume em 1937
}

\author{
Dra. Kate Kangaslahti
}

\begin{abstract}
In April 1937, Wassily Kandinsky, grieved that the city's foreign-born abstract and Surrealist artists had been largely excluded from the Exposition Internationale in Paris that year, approached the director of the Musée du Jeu de Paume to mount a show of contemporary art. Three months later an exhibition opened, small in scale, but bold in ambition: Origines et développement de l'art international indépendant proposed a broad historical survey, plotting the development of twentieth-century art to viewers as a succession of global movements. Despite such lofty intentions, however, the display at the Jeu de Paume, never truly moved beyond an anthology of Parisian painting, and for this reason, and others, the show was a source of professional conflict and personal disappointment to many. Retracing events at the Jeu de Paume through archival records and surviving exhibition materials and examining aspects of the exhibition's organisation, installation and critical reception, this essay also reflects upon the tenuous place that both abstract art and foreign-born artists occupied in French cultural circles in the interwar period and explores the ways that critical and institutional diffidence gave rise to intrigues.
\end{abstract}

\section{Keywords}

Jeu de Paume; Wassily Kandinsky; Christian Zervos; André Dezarrois; Modern Art.

\begin{abstract}
Resumo
Em abril de 1937, Wassily Kandinsky, ressentido pelo fato de os artistas surrealistas e abstratos estrangeiros terem sido amplamente excluídos da Exposição Internacional, em Paris, daquele ano, aproximou-se do diretor do Musée du Jeu de Paume visando montar uma mostra de arte contemporânea. Três meses mais tarde, o museu inaugurou uma exposição de pequena escala, mas bastante ambiciosa: Origens e desenvolvimento da arte internacional independente propôs um amplo panorama da arte do século XX, mostrando para os espectadores seu desenvolvimento como uma sucessão de movimentos globais. Apesar das intenções grandiosas, a exposição no Jeu de Paume nunca realmente foi além de uma antologia da pintura parisiense e, por esse e outros motivos, foi uma fonte de conflito profissional e decepção pessoal para muitos. Retraçando os eventos no Jeu de Paume através de registros de arquivo e do material expositivo ainda existente e examinando aspectos da organização da mostra, de sua instalação e recepção crítica, este artigo reflete sobre o tênue lugar que a arte abstrata e os artistas nascidos no exterior ocuparam nos círculos culturais franceses no período entre guerras e explora as formas pelas quais a desconfiança crítica e institucional deu origem a intrigas.
\end{abstract}

\section{Palavras-chave}

Jeu de Paume; Wassily Kandinsky; Christian Zervos; André Dezarrois; Arte Moderna. 
My friend Alberto Magnelli and I were very sad to hear that the rooms of the "Jeu de Paume" are occupied for the whole duration of the Exposition Internationale and that you see no possibility of exhibiting a few foreign artists living in Paris. It is not only unfortunate but at the same time unfair that "non-figurative" and "Surrealist" artists will not have any opportunity to take part in this Exposition Internationale in Paris, which will bring an enormous number of visitors from around the world.

Wassily Kandinsky. Letter to André Dezarrois, 21 April 1937.

In late April 1937, the Russian-born artist Wassily Kandinsky, who had been living in Paris since the end of 1933, approached the director of the Musée du Jeu de Paume, André Dezarrois, in the hope of persuading him to stage an exhibition of contemporary art to coincide with the Exposition Internationale des arts et techniques dans la vie moderne due to open in May. Kandinsky and his friends, the Catalan sculptor Julio González and the Italian painter Alberto Magnelli, were unhappy that the city's foreignborn abstract and Surrealist artists had not been given the chance to take part in events, particularly pointing to their exclusion from the large display of modern painting that the Ville de Paris was mounting at the Petit Palais under the title Maitres de l'art indépendant (1895-1937)1. The trio regreffully learned that the museum was unavailable; disappointed but undeterred, Kandinsky wrote to Dezarrois immediately after their first unsuccessful meeting, entreating the director to reconsider and emphasising the pedigree and international standing of these two artistic developments to assert the merits of his case:

"non-figurative" painting has existed for more than 25 years... [and] its painters are represented by their works in a large number of museums and private collections, not only in Europe but also in America and even Asia...The "Surrealist" movement is much younger, but even so is quite well known in diverse countries and possesses its own considerable literature (Kandinsky, W. [Letter], 21 April 1937, 9200.1511).

Arguing that visitors to the Exposition Internationale in Paris would otherwise receive an incomplete picture of the city's different artistic movements, Kandinsky urged Dezarrois to correct this imbalance on the walls of his institution.

Let me repeat that we find this situation truly unjust - towards the public and equally towards artists. And let me hope, Sir, that you will nevertheless find a way to restore the equilibrium lost at this moment and to complete the municipality's show by means of an exhibition at the "Jeu de Paume" dedicated to foreign art (Idem). 

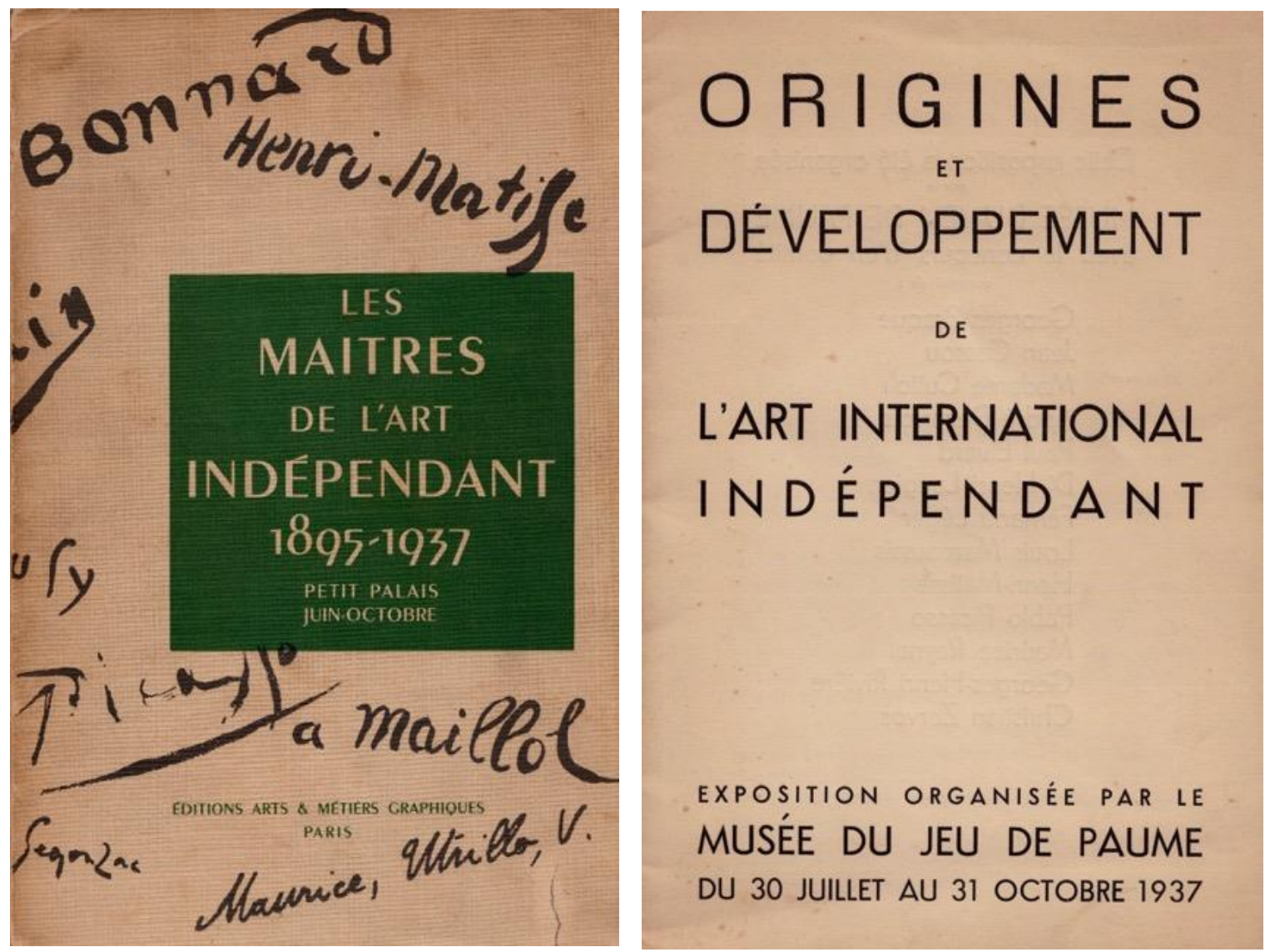

Fig.1. Cover, exhibition catalogue, Maîtres de l'art indépendant, Petit Palais, 1937 (Author's own); Fig. 2. Cover, exhibition catalogue, Origines et développement de l'art international indépendant, Musée du Jeu de Paume (Author's own).

Kandinsky's perseverance proved worthwhile and three months later 177 works by 73 artists took over the museum's first floor, an exhibition small in scale, but much bolder in scope than what he, González and Magnelli had first proposed. In contrast to the aptly named Maitres de l'art indépendant [fig. 1], which showcased the careers of select, individual masters (Petit Palais, 1937), the Origines et développement de l'art international indépendant, as per its title [fig. 2], ostensibly offered viewers a broad historical survey of the most audacious trends in twentieth century art, built as a succession of global stylistic developments. In their ambitions to illustrate the genesis and growth of international contemporary art, its organisers were clearly treading a path forged the year before at the Museum of Modern Art in New York by its director Alfred H. Barr, who had memorably schematised Cubism and Abstract Art as an evolutionary progression of interconnecting - supranational - movements (Barr, 1936: cover). There were, however, some clear differences in the narratives these two exhibitions constructed. Barr's show had extensively embraced developments in Germany, Russia, Holland and Italy and incorporated photography, architecture, furniture, graphic design, theatre and film, whereas the display at the Jeu de Paume never truly moved beyond an anthology of Parisian painting, telling 
the story of modern art in the twentieth century according to its origins and development in France. From modest beginnings to more lofty, yet unfulfilled ambitions, the Origines et développement de l'art international indépendant proved to be a source of conflict and disappointment to those involved or merely interested in its realisation. Much to Kandinsky's particular chagrin, Christian Zervos, the influential editor of the review Cahiers d'Art and secretary general of the exhibition's organising committee, ensured that the best spaces at the Jeu de Paume went to artists already well represented at the Maîtres de l'art indépendant at the Petit Palais, notably Henri Matisse, and, Kandinsky's own bête-noire, Pablo Picasso. Other disgruntled artists went on publicly to protest the show's didactic failings, decrying the omission of a number of foreign artists and demanding the equitable reorganisation of the display. By retracing events at the Jeu de Paume through archival records and surviving exhibition materials, by examining aspects of the exhibition's organisation, installation and critical reception, this essay will reflect upon the tenuous place that both abstract art and foreign-born artists occupied in French cultural circles in the interwar period and explore the ways that critical and institutional diffidence gave rise to personal and professional intrigues.

\section{André Dezarrois and the Musée du Jeu de Paume}

The Jeu de Paume, in its capacity as the state's Musée des Écoles étrangères contemporaines, was both a symptom and cause of the equivocal status that foreign artists practising in Paris between the wars endured in relation to the city's artistic institutions. It was established in 1922 as an annex to the Musée de Luxembourg with the remit of collecting and displaying contemporary art from outside France, a mission strongly implicated by the cultural politics and diplomacy of the era. The many temporary exhibitions the museum hosted during the 1920s and 1930s typically followed interwar convention, developing a likeness of the national self through a corpus of works intended to plot the evolution of a specific national artistic tradition, from its origins and through its defining stages (Passini, 2014: 461). At the beginning of 1937, Dezarrois was planning an ambitious programme of exhibitions according to type at the Jeu de Paume, as he outlined in a letter to the Director General of Fine Arts, Georges Huisman (24 January 1937):

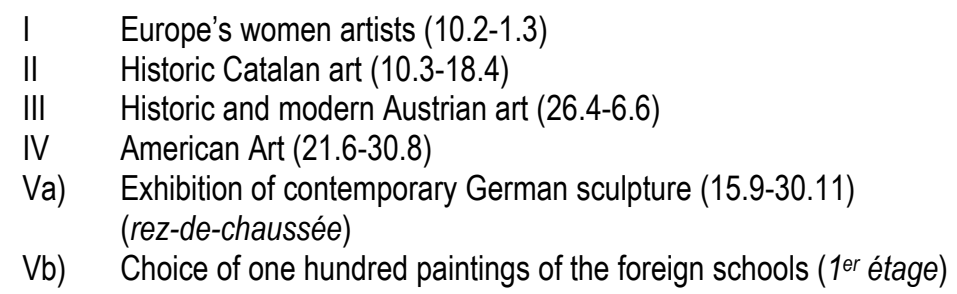

Acknowledging that his programme might appear loaded and logistically difficult, Dezarrois assured his superior that preparations were well underway for all but the last two shows on the list and that the plan answered Huisman's own expressed desire that "museums that [he] directs demonstrate a special activity" during the year of the Exposition Internationale. The brevity of Dezarrois's missive to Huisman, with its simple list, belied the complexity of the political and diplomatic forces driving these events. As civil war raged in Spain, Jean Zay, the Minister for National Education and Fine Arts, who fiercely opposed his own government's declaration of non-invention in the conflict, promoted a display of romanesque Catalan antiquities privileging the region's (artistic) links to France (Amidon, 1992: 302). 
Plans for an exhibition of historic and contemporary Austrian art dated back to the autumn of 1935 and spoke to France and Austria's shared diplomatic interests in emphasising the singularity and longevity of Austrian identity at a time when the country's continued autonomy was already in doubt (Arnoux, 2007: 144-147). Zay and his counterpart at the Ministry of Foreign Affairs, Yvon Delbos, were mutually invested in an exhibition of American art as the "necessary counterpart to the many manifestations that American museums have organised in favour of French art" (31 December 1935). The unrealised scheme for an exhibition of contemporary German sculpture in Paris arose from conversations between Joseph Goebbels and France's ambassador to Germany, André François-Poncet, who described the plan to his superior Delbos as quid pro quo for an exhibition of contemporary French art, Ausstellung Französische Kunst der Gegenwart, slated to open in June in Berlin at the Preussische Akademie der Künste (Cone, 1998: 558).

Given the Jeu de Paume's charged agenda for 1937, and in light of the weight of political expectation its director shouldered as a result, it is not surprising that Dezarrois informed Kandinsky that the museum was unavailable for any additional shows. Later recounting the episode in her memoirs, Nina Kandinsky more tartly opined

that his museum comprised the entire domain of [foreign] modern art and that he therefore shared responsibility for the sort of constrained artistic policy that was practiced in Paris at that time. Naturally he also followed the evolution of abstract art, but he did very little to support it openly... at first he was afraid to make that final leap (1978: 208).

While she was not unjustified in her criticism, Dezarrois was not alone among Parisian curators in neglecting abstract art ${ }^{2}$. Moreover, he had shown himself to be unusually sympathetic to the predicament of the foreign artists living in Paris - neither officially French nor wholly foreign - and in his role as director of the Jeu de Paume he assiduously collected and exhibited their work, not as representatives of their respective "national" traditions, but as members of the École de Paris (Kangaslahti, 2009: 107-108). "The remarkable artists from abroad who come here to work, whose birth, blossoming and evolution our climate has fostered, have contributed to the lustre of our capital and the radiance of its genius", he fervently argued in a letter to George Huisman (6 April 1936). He regularly lobbied Huisman in his bid to acquire works by foreign artists living in Paris, lamenting the arbitrary strictures of nationality and the "incomprehensible absences" imposed upon his collection that rendered the art-historical lesson he was attempting to offer his visitors incomplete. Aware of these sympathies and ambitions, Kandinsky astutely pressed his own case in like terms when soliciting the director to stage an exhibition at the Jeu de Paume (21 April 1937):

I want especially to emphasise the fact that the list of artists that my friend and I presented to you today contains almost exclusively foreign artists and painters who live in Paris and belong to the École de Paris. Presenting their work will give the international public the chance to know a very essential part of this École de Paris.

Kandinsky surely also struck a chord in the way he stressed the existing international reputation of the movements and artists he was nominating: at the beginning of 1937, Dezarrois had similarly sought Huisman's permission (24 February 1937) to buy a small gouache by Kandinsky, Ligne blanche 
(1936), on the basis that American museums had paid and continued to pay very high prices for the artist's canvases ${ }^{3}$.

\section{Wassily Kandinsky and the spectre of Cubism}

The eloquence of Kandinsky's appeal was irrelevant as long as plans for an exhibition of American art continued, but at the end of April 1937 negotiations foundered between organisers at the Museum of Modern Art in New York and administrators from France's Musées nationaux. Implicitly blaming delays on the French side, Alfred Barr wrote to inform Huisman (27 April 1937) that MoMA's officers and trustees now "found it impossible to realize the proposed plans as they desired to do in a manner worthy of the high traditions of the French and of the museum's own standards". In the interim, however, Dezarrois must have been considering, even further developing, Kandinsky's proposal, because in a letter written only two weeks after the American show was shelved, postponed until the following year, the artist wrote to the director (10 May 1937) to commend him at length on his plan "for an exhibition on the history of modern art" that the two had clearly already discussed, which Kandinsky, upon further reflection, found "truly delightful and quite magnificent". He cautioned Dezarrois that the question of history was complicated and the terminology inexact, but he believed the director had succeeded in avoiding the dangers these problems typically posed, with one caveat.

The one point that leaves me in doubt is the difference between the two "movements" both stemming from Cézanne, but that later developed independently of one another. They are: Cubism and "abstract" art (which I prefer to call "concrete") - two movements that came into the world at almost the same time: 1911. Cubism is more of a "brother" to abstract art, but by no means its "father".

"The Constructivists," Kandinsky continued, "generally see their origin in Cubism, which they pushed to the exclusion of all 'feeling' or 'intuition', seeking to arrive at art exclusively by means of 'reason" and (mathematical) 'calculation'". There was, as a result, such a "very profound difference" between abstract art and Constructivism, that it must be emphasised by two distinct categories. Taking a leaf out of Barr's book, Kandinsky further asserted this difference by presenting Dezarrois with a carefully typed graphic clarification of abstract art's divergent path away from both Cubism and Constructivism:

1. Abstract (concrete) art

2. Constructivism

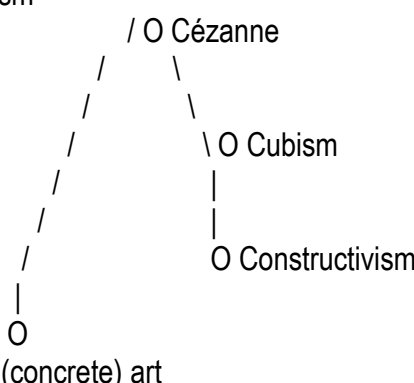

Kandinsky's visual insistence on this very point reflected his personal dissatisfaction with the schematic timeline Barr had put forward the previous year in Cubism and Abstract Art and which 
plotted the history of modern art as a deterministic march to abstraction concluding in the two endpoints of "non-geometric abstract art" and "geometric abstract art" (Noyes-Platt, 1988: 284). Although Barr's scheme certainly brought some clarity to the question of development, Kandinsky objected to his focus upon external - apparently autonomous - formal influences, which minimised differences between countries and downplayed the important part played by the artist's own inner drive and psychology. "I have never worked "programmatically", he clarified to Barr (22 June 1936), "nor have I ever forced myself into a formal language that did not originate in me and develop slowly". More generally, Kandinsky was also frustrated by an exhibition and catalogue that seemed to elucidate art in the twentieth century as a family tree tracing the ancestry and progeny of Cubism. While the artist was circumspect in raising this point directly with Barr, in an article titled "Abstract Art", published in 1936 in the Dutch periodical Kroniek van hedendaagsche Kunst en Kultur, Kandinsky explicitly lamented that "it is remarkable how Cubism, which is just as old (or young) as abstract painting, has nonetheless become 'historical' and hence sacrosanct" (Kandinsky, 1994: 785). Such complaints plainly informed the artist's hopes for a subsequent exhibition in Paris in 1937 and his insistence to Dezarrois that abstract art, Cubism and Constructivism must be clearly distinguished from each other in terms of their respective "points of departure, 'methods', and 'psychology"' (10 May 1937). He also notably argued here for the inclusion of Dada, not only because it was "without doubt the starting point of Surrealism" but as a foil to those very "mathematical" or geometric styles from which he also sought to separate himself: "Dada fought to replace logic with illogic, a fact of great importance because art has never been logical, and the laws of art very often differ from 'mathematics'." In a position now to offer this museum's director his advice, Kandinsky was optimistic that an exhibition at the Jeu de Paume would "finally be able to show in a clear and persuasive manner, the organic, natural and necessary development of modern art from its roots - Cézanne, and bring order to the confusion and misunderstandings that accompany the subject in every country".

The artist's high expectations were forestalled, however, due to the intervention of Christian Zervos, who was incensed when he learned in late May that Kandinsky had convinced Dezarrois to stage an exhibition of contemporary art at the Jeu de Paume. In point of fact, Kandinsky, Magnelli and González had first turned to the editor of Cahiers d'Art in their hope of organising a show devoted to foreign artists living in Paris who had not been invited to the Maîtres de l'art indépendant, and Zervos had initially been enthusiastic about the idea, going so far as to draw up a list of participants with Magnelli ${ }^{4}$. Yet, much to the trio's hurt surprise, Zervos lost any interest in the plan when it became clear, as Kandinsky pointedly wrote to the editor (1 June 1937), that 'the 'great artists' of Paris had been given the chance to exhibit their works....at the Petit Palais". Only then, at the advice of the dealers Jeanne Bucher and Marie Cuttoli, did Kandinsky and his friends approach Dezarrois, and given that Zervos had not wanted to exert himself on behalf of those still excluded from the Petit Palais, the artist could not comprehend his ire: "I can admit I would have rather hoped that the success of this exhibition might bring you real pleasure, if only on account of an injustice set right". Zervos, however, plainly resented changes the trio had made and their exclusion of his personal favourites from the suggested list of participants he had compiled with Magnelli. "If the names of Braque, Léger and Picasso were removed," Kandinsky reasoned, "it is obvious that these artists no longer needed to be exhibited together with the greater possibilities offered to them by the Petit Palais". No slight had ever been intended, either to Cahiers d'Art or Zervos personally, and, as Kandinsky went on to remind his 
erstwhile friend and collaborator (2 June 1937), "from the moment that M. Dezarrois agreed to organise the exhibition, he alone become responsible for the list of participants".

\section{Christian Zervos and the "birth of a new order"}

The prestige conferred by the patronage of an official state museum, however, clearly reignited Zervos's interest and he succeeded in re-staking his proprietorial claim over plans for the show, assuming the pivotal role of secretary general of its organising committee at the beginning of July. The committee boasted impressive names from the city's cultural elite, including Jean Cassou, Marie Cuttoli, Paul Eluard, Henri Laugier, Maurice Raynal, and George-Henri Rivière, as well as a number of artists already honoured by the Petit Palais, namely Henri Matisse, Pablo Picasso, Georges Braque, Fernand Léger and Louis Marcoussis. Ultimately, however, it was Zervos who drove proceedings and who approached artists, dealers and collectors among his acquaintance on the subject of their participation. "The Musée du Jeu de Paume is, on my advice, organising an exhibition titled: Origines et développement de l'art contemporain international. De Cézanne à nos jours", Zervos wrote to Paul Klee (apud Derouet, 1992: 140).

I would like you to be well represented, by 12 works at least. I went yesterday to see M. Adolphe Kann to get the four paintings he possesses. For the rest, I would like you to take care of it personally so that the pieces are completely characteristic...Please let me know as quickly as possible how you see your collaboration so that I can have the director of the museum write to you.

The vast majority of official requests for specific works that Dezarrois subsequently addressed to lenders mention an earlier discussion between the recipient and either Zervos or his wife Yvonne, like, for example, the director's letter to Matisse (15 July 1937):

Following your meeting with M. Zervos, I will arrange to have collected from you the works listed below:

1. Cézanne, Rochers de Bibémus

2. Cross, Les bouilleurs de cru

3. Polynesian sculptures once belonging to M. Eluard

4. Matisse, Luxe

5. Matisse, Paysage

M. Zervos telephoned you from my office to see if you would equally like to lend us a canvas from the last five years.

The objects in question, including not only examples of Matisse's own painting, old and new, but also works by his French forebears Paul Cézanne and Henri-Edmond Cross, indicate what sort of account of modern art Zervos now sought to fashion. The committee he headed more plainly established the parameters of that account in its petition to the director of the Musées nationaux, Henri Verne (13 July 1937), to borrow four artworks from France's national collections, Pierre-Auguste Renoir's Les baigneuses (1919) and Paul Gauguin's Les Tahitiennes (1891) from the Louvre, and Georges Seurat's Le cirque (1891) and Henri de Toulouse-Lautrec's Panneaux pour la baraque de la Goulue (1895) from the Musée de Luxembourg. 
These paintings appear indispensable to the committee to reinforce the demonstration it is attempting in this unprecedented exhibition, which, at a moment when many foreigners are visiting Paris, aims to complete the show currently taking place at the Petit Palais on a modest but well considered basis... [and] with respect to the origins and development of the Fauvist, Cubist and Surrealist movements and their influence upon contemporary painting.

All the while touting the exhibition's "external perspective", Zervos and his colleagues here declared their intention to illustrate the story of international art in terms of origins, developments and influences that were, if not exclusively French, then decidedly Parisian.

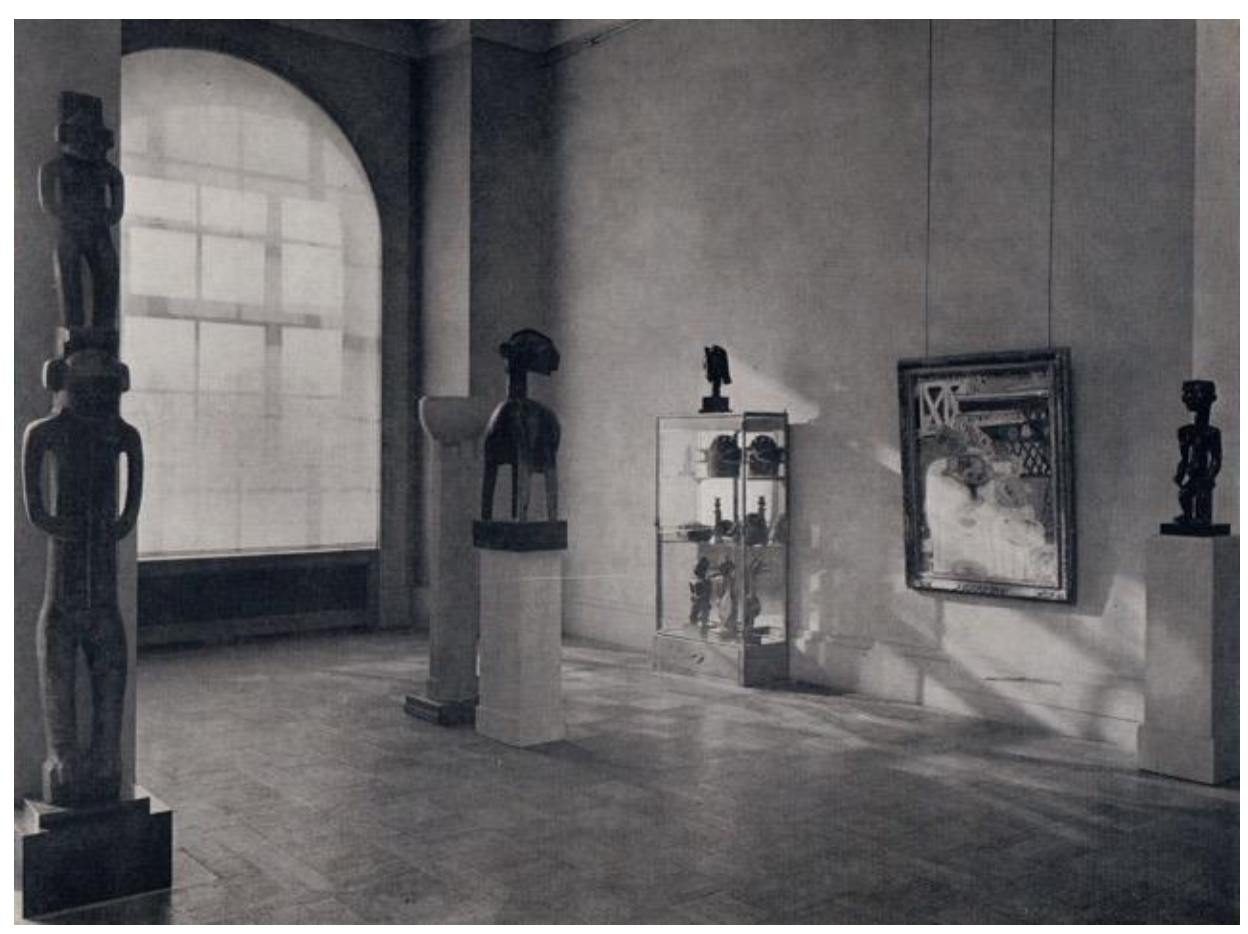

Fig. 3. Photograph of salle $X$, "Origines et développement de l'art international indépendant" at the Musée du Jeu de Paume, Paris, 1937, showing African sculptures and Pierre Bonnard's La Table [The White Tablecloth] (1924). Reproduced in Hommage à Yvonne Zervos. Paris: Tournon, 197, n.p. (Author's own).

Conversely, when the Origines et développement de l'art international indépendant opened on 30 July 1937, the short accompanying catalogue, uncredited but almost certainly authored by Zervos, deferred - on paper - to the Jeu de Paume's official mission, announcing that "this exhibition is devoted to artists from the Foreign Schools. French participation has been reduced to single works that explain the sources upon which these artists have drawn" (Musée du Jeu de Paume, 1937, n.p.). Accordingly, the first room of the museum's upper floor, Salle X [fig. 3], was dedicated to those Impressionist, Postimpressionist and Symbolist forebears "who have animated the painting of today." More unusually, a small assortment of African and Polynesian masks and sculptures also occupied the alcoves of this space, in recognition of the way "the painters of today were turning towards primitive peoples at the 
same time that they drew inspiration from their elders," but these uncatalogued objects were secondary sources to the primary focus of the salle d'honneur. The French State had granted the committee's request for Gauguin's Les Tahitiennes and Seurat's Le Cirque and also loaned La Charmeuse de serpents (1907) by Henri Rousseau; the wealthy Parisian collector Marcel Kapferer lent two paintings each by Renoir, Odilon Redon, and Vincent Van Gogh, and one by Edgar Degas. There was an additional work by Gauguin, and two by the Belgian Symbolist James Ensor, but among these nineteenth-century giants, Paul Cézanne, as the very title of the catalogue essay announced [fig. 4], loomed largest. It was he who had suggested to the next generation of artists that "it was no longer a matter of the painter reproducing an anecdotal fact but first and foremost building a pictorial reality", and he who had "thus taught them to create instead of imitate, to constitute nature rather than to reconstitute it". Les Rochers de Bibémus (1900-1901), which had come from, and was credited to, Matisse's personal collection, served as a particularly notable link within the genealogy of modern art the display plotted, proof of the "precious support" that Cézanne's œuvre had lent the painter, whose own aventures followed in the next room. In this scheme, the Fauves marked the first step in an artistic journey that began once young artists found themselves unshackled from the chains of imitation. Their newfound liberty manifested itself in Fauvism's "magnificent and total abandonment to the joy of light" and "an obsession with colour", seen in Salle XI through the early painting of Matisse, Braque, André Derain, Othon Friesz, Georges Rouault and Maurice de Vlaminck. The only work painted by a foreign artist was, somewhat curiously, Peintres à la campagne (1906) by the Hungarian painter Béla Czóbel ${ }^{5}$.

\section{E C É Z A N N E}

\section{A L'ART NON FIGURATIF}

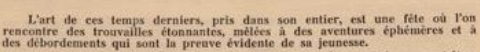

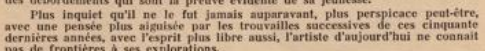

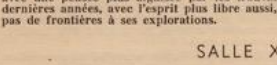

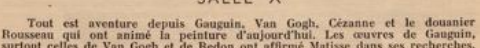

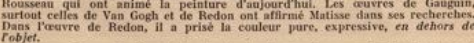

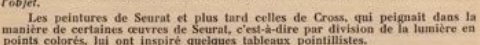

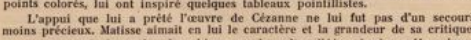

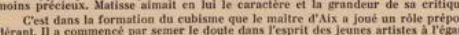

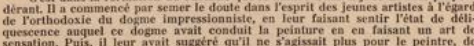

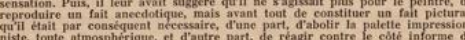

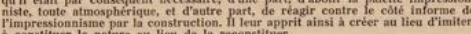

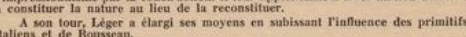

tatilean et de Roussean.

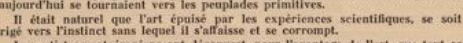

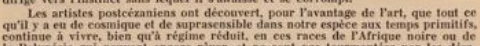

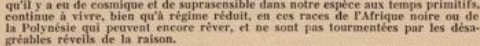

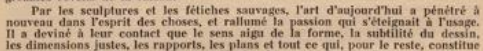

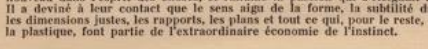

(a)

Fig. 4. De Cézanne à l'art non-figuratif," main essay in Origines et développement de l'art international indépendant: exhibition catalogue. Petit Palais: Paris, 1937, n.p. (Author's own). 
The small number of Fauvist works exhibited - twelve in total - and the size of the space itself nevertheless signalled the movement's (lesser) relative importance in the overall plan of the exhibition; Fauvism's audacious experiments with colour were merely the first giddy flush of an artistic youth, whereas Cubism, according to Zervos's catalogue, heralded nothing less than the "birth of a new order" (Musée du Jeu de Paume, 1937, n.p.):

It has purified art of deliquescent elements...it has cleansed and refreshed the vision of artists, it has re-educated in a manner of speaking their plastic instinct, it has taught them to organise their paintings, it has liberated their spirits from bygone principles. Cubism has given value to all the elements that lie in our hands, the practical sense of which we had lost.

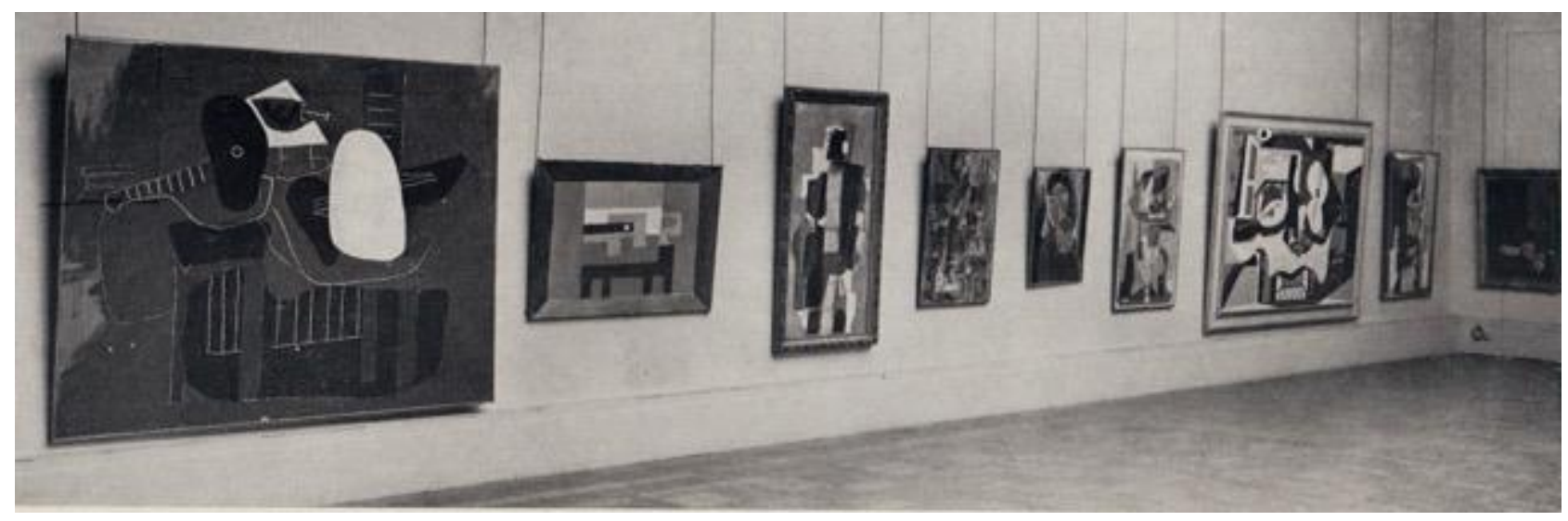

Fig. 5. Photograph of salle XII, "Origines et développement de l'art international indépendant" at the Musée du Jeu de Paume, Paris,1937, showing a selection of paintings by Pablo Picasso. Reproduced in Hommage à Yvonne Zervos. Paris: Tournon,

1970, n.p. (Author's own).

Within the Jeu de Paume itself, subverting the show's implicit chronology, visitors actually caught their first glimpse of this liberated, yet newly rigorous, plastic language before the exhibition proper even began on the first floor. Works by the Salon Cubists, including Jean Metzinger, Albert Gleizes, Francis Picabia, Jacques Villon, Auguste Herbin, Léopold Survage and Roger de la Fresnaye, hung in the rooms to the left and right of the ground floor entrance, acquainting viewers with Cubism's fractured forms, reduced palette and flattened perspectives in advance of the main display. This Cubist prologue then allowed Pablo Picasso to reign supreme in Salle XII on the museum's upper level, where eleven of his paintings, the most of any artist in the exhibition, occupied pride of place along one long wall [fig. 5], complemented by contributions from the movement's other chief protagonists, Georges Braque, Juan Gris and Fernand Léger. The catalogue emphasised Cubism's radical conceptualisation of space, "not as something imitated, but something imagined", and the canvases on show traced that reinvention of pictorial space, from the Proto-Cubism of Picasso's Femme et enfant (1907) and Paysage (1908), to the height of analytical complexity in the monochromatic fragmentation of the artist's Ma jolie (1911) and Braque's La portuguèse (1911). There was a greater number of works from after 1912, however, at which point painters arranged flat, coloured forms on their canvases and began "using new materials, papiers collés, sand, and imitating wood, marble, wallpaper", eradicating all 
suggestion of illusionistic perspective and "constructing space by the sole fact of placing one object in front of another". Notably prominent among the examples of this synthetic process were three canvases that Matisse painted between 1915 and 1916, Le rideau jaune, La leçon de piano, and Les marocains [fig. 6]. Atypical of his œuvre, these sharp, geometric compositions purged of all descriptive detail - purified of deliquescent elements - more purposefully illustrated the catalogue claim: the manner in which Cubism awakened artists' plastic instincts, cleansed their vision and taught them to reorganise their canvases.

As the catalogue narrated the display, Cubism was the decisive step in the evolution of international contemporary art, and subsequent developments served as a measure of its importance and effect (Musée du Jeu de Paume, 1937, n.p.):

PURISM, of which Ozenfant is the creator, comes directly from Cubism, against which it will soon react...

NEOPLASTICISM The influence of Cubism on 'new plastic expression' is undeniable, according to the opinion even of the leader of this trend, the painter Mondrian. During the war, a painting from Paris reached this Dutch group, which was seeking to chart a new path... [it] considered this Cubist work as the highest form of painting...

CONSTRUCTIVISM, also known as réalisme constructeur is equally a child of Cubism...

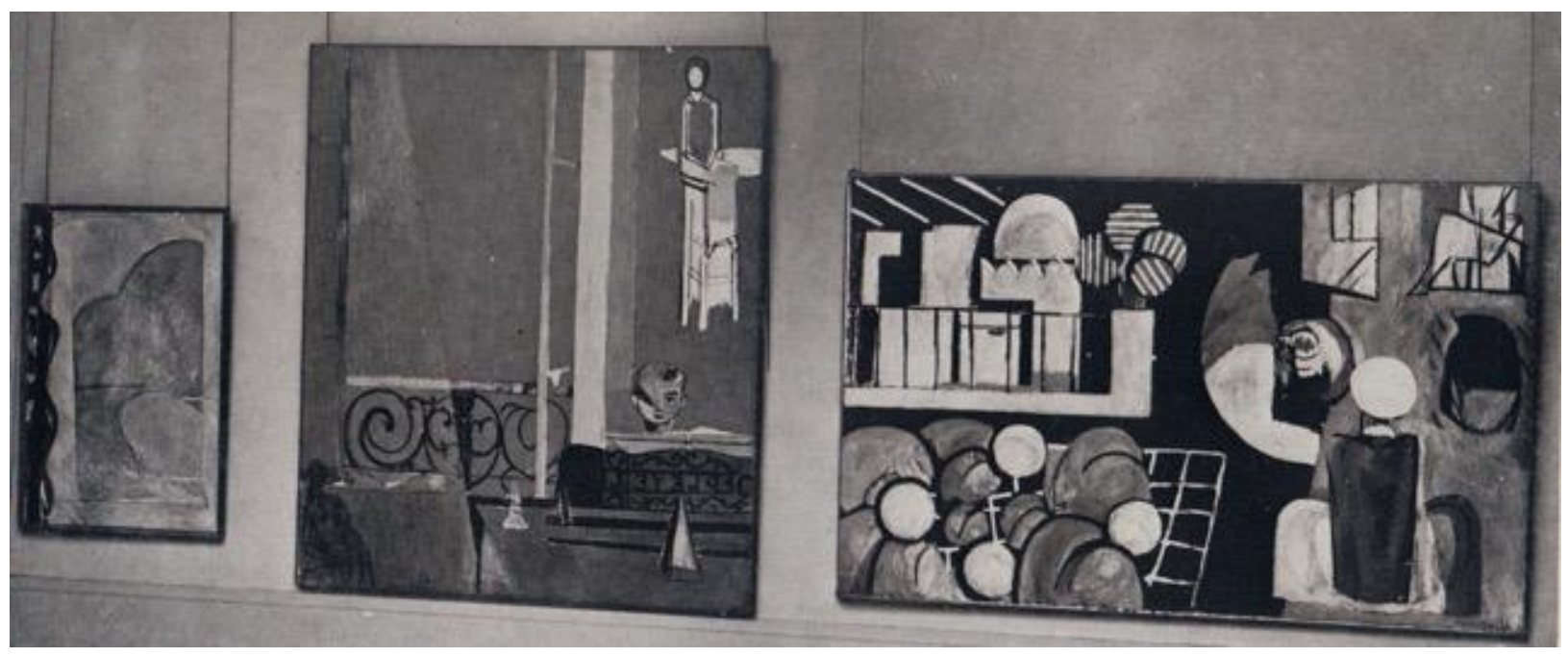

Fig. 6. Photograph of salle XII, "Origines et développement de l'art international indépendant" at the Musée du Jeu de Paume, Paris, 1937, with paintings by Henri Matisse between, from left to right: La Veranda [The Yellow Curtain] (1915), La leçon de piano (1916), and Les marocains (1916). Reproduced in Hommage à Yvonne Zervos. Paris: Tournon, 1970, n.p. (Author's own).

Cubist painting even anticipated, or rather precipitated, Surrealism, for it was first Cubism's "distinction to have drawn poetry from everything that seemed to us to be deprived of it...to have magnificently shown us the surreality of the things that surround us." It was "early Cubism [that] reconnected our dulled senses with spirit of things" and so Surrealist painters were, by extension, building on the foundations of their Cubist forebears, in wanting "to create poetry from that which is not visible". The 
installation of works in turn reinforced the narrative, for at this point the display abandoned the sequential premise with which it began and, relative to the central place Cubist painting occupied both figuratively and physically within the exhibition, succeeding developments received cursory, even disorderly treatment in the Jeu de Paume's remaining spaces. There were a number of works by Surrealist artists, several, unsurprisingly, lent from the collection of Paul Eduard, a member of the organising committee, but their haphazard arrangement throughout the last three rooms of the exhibit diluted the force of the movement's presence. Salvador Dali featured in Salle XIII, alongside the metaphysical painter, Giorgio de Chirico, and Marc Chagall, whereas a single canvas by Yves Tanguy and two by Man Ray hung in Salle XIV, and those by René Magritte appeared only in Salle XV; conversely, there were works by Max Ernst in both Salles XIII and XIV, and paintings by Joan Miró in all three rooms. Additionally, while the Neoplastic Compositions of Piet Mondrian were also exhibited in Salle XIV, next to the Purist canvases of Amedée Ozenfant and three Constructivist Constructions by Antoine Pevsner and Naum Gabo [fig. 7], the work Bas-relief polychromé rond (1936) by César Domela-Nieuwenhuis, Mondrian's compatriot and the only other representative of De Stijl, was exhibited in the final room.

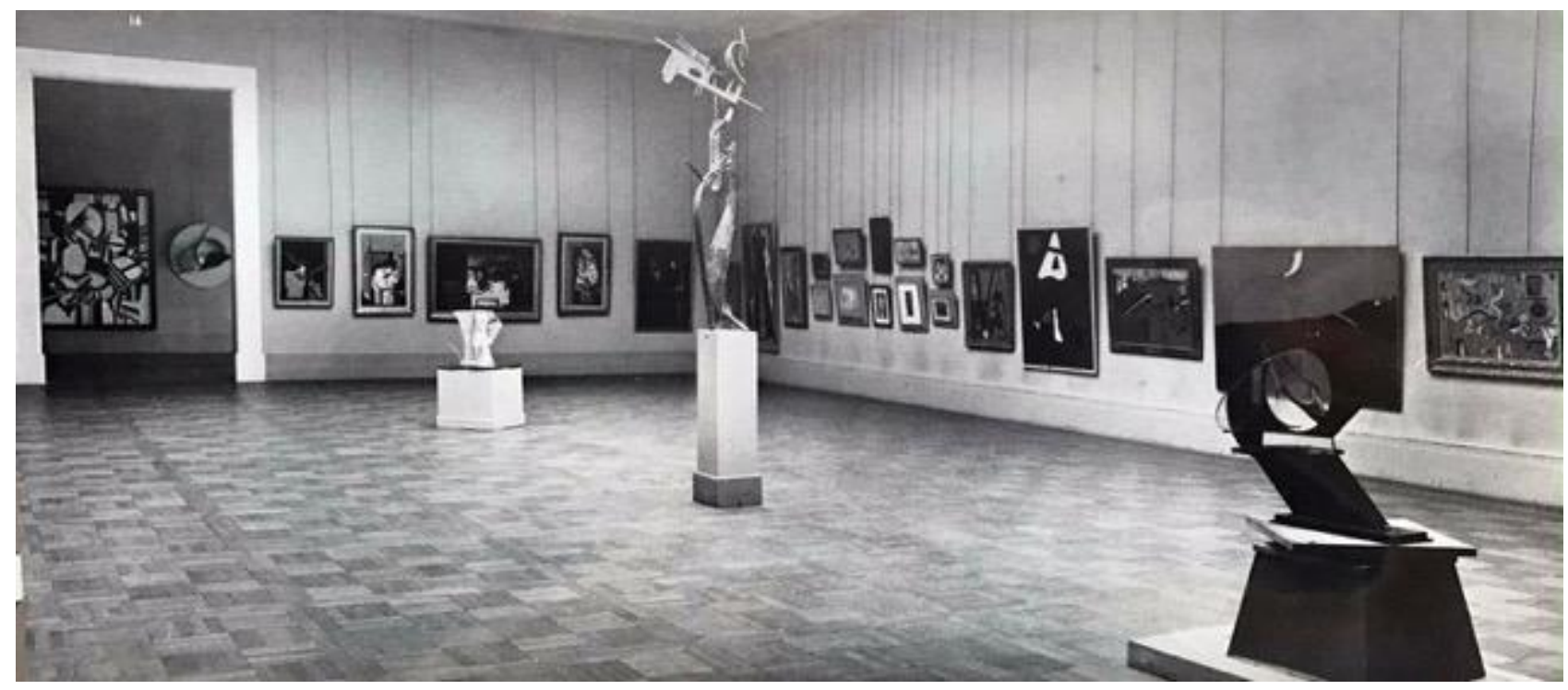

Fig. 7. Photograph of salle XIV, "Origines et développement de l'art international indépendant" at the Musée du Jeu de Paume, Paris 1937, showing paintings by Joan Miró and sculptures by (left to right) Naum Gabo, Julio González, and Antoine Pevsner. Reproduced in Hommage à Yvonne Zervos. Paris: Tournon, 1970, n.p. (Author's own).

Wassily Kandinsky, who had initially proposed an exhibition devoted primarily to Surrealism and abstract art and who, in so doing, had taken pains to clarify the independent origins of his own painting, was understandably irritated by aspects of the display and by the "explanatory information provided by the catalogue", which, he complained to André Dezarrois (31 July 1937), "does not exactly correspond to reality." Drawing the director's attention to "the large canvas now on show at the 'Jeu de Paume' [that] was painted in 1912, and [in which] there is no Cubist influence to be seen", he once 
again emphasised that "my form and Cubism can be seen as two lines that, independent of one another, received the same first shock from Cézanne and later from Fauvism". Kandinsky's frustration reflected in part the initial care with he had selected five works to represent the spectrum of his œuvre and communicated his wishes for their installation to Dezarrois (15 July 1937), hoping to show his audience that he was a pioneer and not a mere (Cubist) disciple.

Unfortunately, I had to omit the "roots" of my "non-figurative" form, that is to say a canvas from 1911 (Composition No. 4), in which traces of objects remain clearly visible... Here are the periods presented:

L'arc noir, 1912, "lyrical" period (one of my first "non-fig." canvases)

Sur blanc, 1923, "cold" period

Développement en brun, 1933, "deepened surfaces" period

Entre deux, 1934 et Courbe dominante, 1936, "synthetic" period...

I would respectfully ask that you hang my canvases as I have indicated on the attached list-something very important for my painting...

I thank you very cordially for having given me the chance to show, for the first time, the development of my art to the Parisian public.

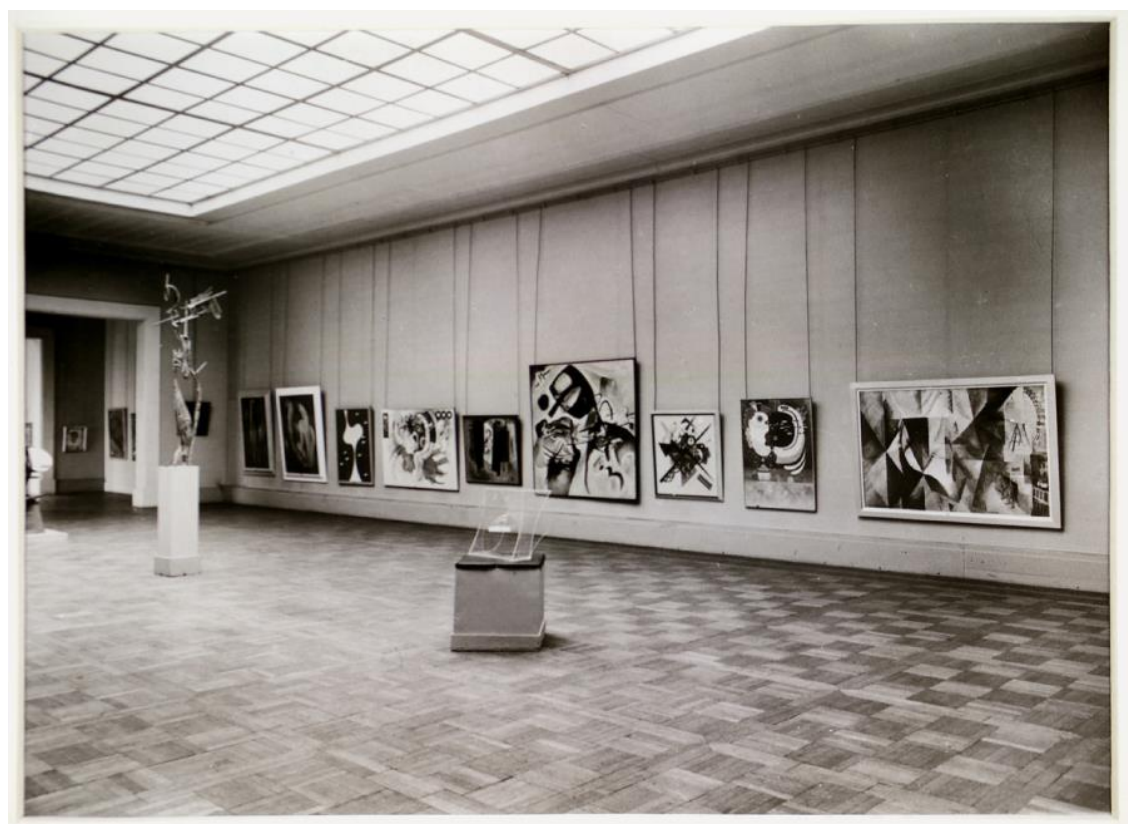

Fig. 8. Photograph of salle XIV, "Origines et développement de l'art international indépendant" at the Musée du Jeu de Paume, Paris 1937, showing works by Wassily Kandinsky, left to right: Courbe dominante (1936), Développement en brun (1933), L'Arc noir, (1912), Sur blanc (1923), Entre deux (1934). Photo @ Bibliothèque Kandinsky, Centre Pompidou, MNAM-

However irked Kandinsky may have been that his paintings were not displayed in the order he had specified [fig. 8], he remained sensible of the opportunity and preferential treatment he received". "My own work had a good position", he wrote to Josef Albers (apud Weber and Boissel, 2009: 107), "not quite sufficient, but acceptable. I only got that much space because I had been personally invited by 
the director of the museum". Alluding to the "dramatic Développement" of the exhibition, he lamented to his friend that "because so much time was wasted on quarrels and intrigues...the only foreigners able to take part were those living in Paris" (apud Weber and Boissel, 2009: 103), although this was precisely what he had originally proposed. He now further explained to Albers that during preparations two lists had been drafted,

a shorter one, with the names of artists living in Paris, and a longer one, which also had names of artists from abroad. The choice between the two lists depended on two things the size of the exhibition rooms and the length (or rather shortness) of the time that remained for setting up the exhibition (apud Weber and Boissel, 2009: 107).

Thanks to the "collaboration' of M. Zervos", Kandinsky bitterly noted, several of the Masters of Independent Art from the Petit Palais "got one of the largest rooms [at the Jeu de Paume] (e.g. Picasso had one of the longest walls)", leaving neither sufficient time nor space to make the show truly international. Despite some strong misgivings, however, the artist insisted that "one should never allow details to override the WHOLE", and, according to Kandinsky, "the whole, or the main purpose and main value of the exhibition was the fact that, for the first time, abstract art in particular was given an official showing".

\section{André Breton and a crew of discontents}

Not everyone, however, was quite so magnanimous in response to the exhibition's perceived shortcomings and at the beginning of August, shortly after the show opened, a group of independent artists spearheaded by André Breton publicly complained. In an open letter, subsequently published in the journal Beaux-Arts and addressed to Prime Minister Camille Chautemps, to Jean Zay, and to Georges Huisman, the group questioned whether organisers had sufficiently privileged the work of foreign artists or consistently restricted French participation to those exceptional examples formative to the creation and development of international contemporary art. "Among the French artists, some have been exhibited according to the principle adopted and are represented by a single work, while...certain others have much too great a representation", the letter opined (En marge de l'Exposition du Jeu de Paume, 1937: 4). "A [further] number... have been unjustly excluded". In the same vein, "we have observed that plenty of foreign artists, whose importance and contribution are indisputable and universally known, have been neglected". On this point, the group's criticism was undoubtedly valid: 73 artists appeared in the exhibition and while 43 were nominally foreign, the vast proportion of these artists had been limited to one, at most two, works in the display; only Marc Chagall, Salvador Dalí, Giorgio de Chirico, Max Ernst, Juan Gris, Wassily Kandinsky, Paul Klee, Jacques Lipchitz, Louis Marcoussis and, naturally, Pablo Picasso secured a greater representation. Yet as this very list of names indicates, and as Kandinsky had written to Albers, most of the foreign contributors were artists who, like Picasso and Gris, had spent the better part of their careers in Paris; some, including Chagall, Lipchitz and Marcoussis, although listed in the catalogue by their nationality at birth, were already naturalised French citizens. Paul Klee was a rare exception to this rule, but he was popular among French collectors, as Kandinsky had also explained: "of course, Klee was represented, as they could get his work here and he is very well known here" (apud Weber and Boissel, 2009: 105). In other words, the works on view simply did not support the catalogue's claim that the display was "dedicated to artists of the Foreign Schools" (Musée du Jeu de Paume, 1937: n.p.); to the contrary, developments 
beyond the microcosm of the French capital received little or no attention. Many of the unacceptable omissions the protesters named in their communiqué, arranged according to place of origin, underscored the poor showing of De Stijl and Dada and the virtual absence of Expressionism, Constructivism and Futurism (En marge de l'Exposition du Jeu de Paume, 1937: 4):

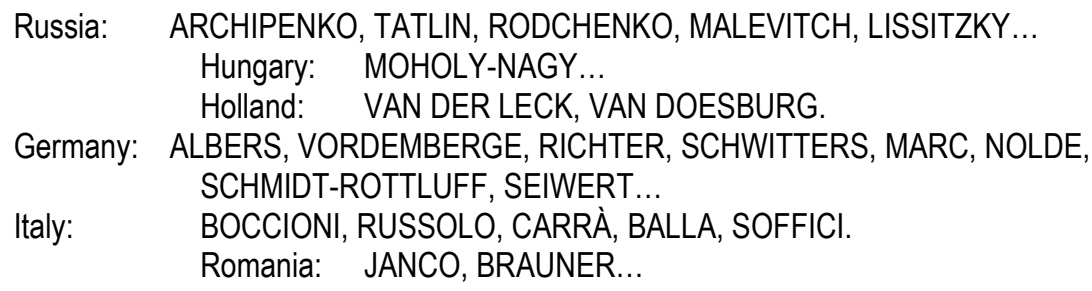

Given that the aim of organisers had been to create a didactic display, "the result present[ed] a grave danger both to the education of the public and its relationship with artists" and "for all these reasons, the undersigned demand[ed] the equitable reorganisation of [the] exhibition".

There had already been signs of brewing discontent during preparations for the show, when the critic Pierre Guégen wrote to André Dezarrois (9 July 1937), hoping, in vain, to see the work of Hungarian painter Arpad Szenes and Portuguese artist Maria Elena Vieira da Silva included, whether or not they had been proposed by what Guégen archly described as "the triumvirate Breton, Zervos, Kandinsky". If their names had not been put forward it was because "the triumvirs (except Kandinsky, who likes them but who is weak and has his own candidates) do not know their works well, for lack of time and because there are so many artists" and he appealed directly to Dezarrois as "the true patron of the exhibition, you who thus have concrete control over all this abstraction!"7 Dezarrois, however, had been content to delegate - to relinquish - a large share of that control to the organising committee and its secretary general. When the director explained matters to his administrative superior, Henri Verne, some weeks after the show had opened, he readily ascribed the ensuing critical storm to Christian Zervos, even as he downplayed its gravity and impugned the motives and importance of those who were publicly objecting:

As for our exhibition, praised by some, debated by others, it stirs up the protests of those who we had to exclude. I did warn the secretary general of the Committee, M. Zervos, that his intransigence was provoking the anger of those rejected. Besides which, I had always declared that after the leaders and initiators I would, in the course of a second exhibition, show the disciples and, well, the imitators. It is they who are howling, or who were howling at the end of July, because since then its all quiet. (Dezarrois, [Letter], 12 September 1937, 20150042/50).

Zervos himself had expected, nay invited, the impending commotion, because the catalogue foreword he clearly wrote pre-emptively defended the uncompromising nature of the committee's selections, in a manner all but designed to provoke:

Among the foreign painters and sculptors, a certain number have been omitted whose work does not lack plastic quality. It is that our choice was limited to those artists who have initiated something much more vital in their work. 
Have we lacked tolerance? Should we have followed a wider path, or, more conveniently, consented to satisfy everyone? We do not think so. The choice certainly has its inconveniences and it is hardly because an artist meets our expectations that he will in the future be the greatest. But we wanted to show a kind of handbook of new expressions, those in which the aesthetic adventure of today best reveals itself and in which the thrill is the most acute. From this perspective, our choice was well considered, and it is unlikely that a significant man could have escaped us (Musée du Jeu de Paume, 1937: n.p.)

Unsurprisingly, the catalogue itself, in which Zervos both flaunted the committee's exclusions without apology and issued his own idiosyncratic account of contemporary art, also attracted the censure of protesters: "we oppose the wording of the foreword and the explicative text, which are untrue" (En marge de l'Exposition du Jeu de Paume, 1937: 4). In a note accompanying a copy of the open letter sent to Huisman, the artist Auguste Herbin, one of the signatories, even tacitly implied that Zervos was the target of their ire by stating that "Monsieur Dezarrois, director of the museum, is not the issue" (7 August 1937).

What the protesters failed to take into account in their criticism was that the exhibition was an improvised affair, and despite what Zervos defiantly wrote in his preface to the catalogue, the works on display at the Jeu de Paume had been selected on practical as much as aesthetic grounds. "There was not enough time to make the show truly international", Kandinsky had admitted to Albers (apud Weber and Boissel, 2009: 103); nor had there been sufficient funds. In the initials stages of planning, Dezarrois had written to Gino Severini (15 July 1937) expressing his "infinite regret" that "it is impossible for me to assume the cost of transporting your canvases, as well as those of Boccioni and Carrà, from Rome to Paris and back again". As a result, the presentation of Futurism was confined to what could be quickly and locally sourced: a 1913 painting by Severini from the collection of Dr René Allendy, which hung among the Salon Cubists at the museum's entrance; a lone Composition by Umberto Boccioni, listed as the final work in Salle XV; and, also in the last room, Simultaneité cosmique (1928) by Enrico Prampolini, who lived chiefly in Paris, and whose inclusion Kandinsky had personally suggested to Dezarrois "since an Italian Futurist would be necessary" (10 May 1937) $)^{8}$. In the lengthy description of the show that Zervos later wrote for Cahiers d'Art, the editor himself regretted that "this very important movement [was] only represented by Boccioni and Gino Severini" (Les Expositions, 1937: 163). He repeatedly deplored the shame that the museum had received no funding for "such an important exhibition" and that "for lack of the means necessary to transport the paintings... M. Dezarrois had had to give up bringing Futurist and Constructivist works from Italy and the U.S.S.R", leaving his readers to infer more than once that administrative parsimony had thwarted ambitions for a more comprehensive survey. Suppressing any mention of his own involvement in proceedings, Zervos extolled the director's persistent "courage in showing in a national museum trends seen as pernicious or ridiculous", and asserted the exhibition's interest and value, going so far as to invoke tacit comparison with the twin shows that Alfred Barr has staged the year before at the Museum of Modern Art, Cubism and Abstract Art, and Fantastic Art, Dada and Surrealism:

Up until now, as much in France as in other countries, sometimes Cubism has been exhibited, sometimes Surrealism, sometimes lastly non-figurative art. It is the distinction 
of the Musée du Jeu de Paume to be the first to have grouped and confronted the ensemble of these artistic tendencies (Les Expositions, 1937: 162).

Zervos's self-serving claim was not wholly disingenuous, but it both discounted the depth and breadth of the exhibitions at MoMA and conveniently obscured the truth that, in the absence of German Expressionism, Russian Constructivism and Italian Futurism, the display at the Jeu de Paume narrated the story of modern art in terms of movements as they originated or developed in France's capital ${ }^{9}$.

The exclusions which precluded the Origines et développement de l'art international indépendant from taking on a truly international aspect went unremarked in the only other two contemporary published accounts of the exhibition, which based their criticism on a different exclusivity perceived in the art on display: its abstract nature. André Lhote, the erstwhile Cubist turned figurative painter who strongly advocated for the retour à l'homme, was vociferous, if hardly impartial, in his disappointment in the pages of the Nouvelle revue française. "To believe the organisers, grouped around M. Zervos, independence does not signify the rejection of outdated formulas, the search for an original language to express modern man, but solely abstract art, without any link to reality. We only find painted surfaces here, and not images of objects, except in the Surrealist paintings of Dalí and Max Ernst, where objects are assembled in an order other than that of nature". The accompanying catalogue was, furthermore, a fittingly "comprehensive survey of extremist theories" (Lhote, 1937: 516). Raymond Cogniat in Beaux-Arts was slightly more accommodating in his assessment, but similarly took exception to the wider pretence of the title:

Abstract art in effect occupies a considerable place in our time, and up until now no large manifestation of the whole had ever been organised in Paris. There was then a large agenda to show the state of one of the trends in Independent Art. But we debate the very title of the exhibition, for to announce International Independent Art", without any clarification, suggests that in the minds of organisers no other creation, no other tendency exists (Cogniat, 1937: 1).

Insisting that abstract art was the primary focus of the exhibition, these reviewers did not ignore the other "tendencies" on show so much as dispute the validity of their presence within the display. Braque and Picasso might well "preside over this show [but] even their barest paintings never cease to evoke the moving forms of life," wrote Lhote. Stranger still for him was the inclusion of Derain and Vlaminck, Matisse and Bonnard, "so arbitrarily enrolled in this enterprise 'against nature'... the works representing them ingeniously chosen from among the most stripped bare" (Lhote, 1937: 516). While Cogniat particularly admired the part "devoted to Cubism with the canvases of Picasso from circa 1910, the works of Braque, Gris, Léger", he noted that the first half of the display "appears rather like a summary of the current exhibition at the Petit Palais and hence somewhat pointless." Yet Cogniat not only contested the place of Fauvism and Cubism in this "insufficient" exhibition of abstract art, he questioned whether abstract art even belonged in such exhibition in the first place, set apart as it was by "its fetishistic aspect, its plastic conception outside reality, its taste for...monsters as well as a certain severe cruelty, a kind of demonic delirium", a character only accentuated here for the critic by the proximity of actual fetishes, the African and Oceanic objects. "The traditional presentation of a museum could not possibly suit something so exceptional", Cogniat determined, but what he arguably 
meant was that the "unreal world" of abstract art, "at times troubling and provocative", had no rightful place on its hallowed walls (1937: 6).

\section{Conclusion}

The different parties who claimed an interest in the Origines et développement de l'art international indépendant at the Jeu de Paume in 1937 pushed and defended their respective causes with disproportionate zeal, an urgency seemingly at odds with the prize at stake. Yet this is largely the point. During the interwar period, French museums only infrequently welcomed foreign-born artists and rarely accommodated abstract artists; the limited ground they succeeded in occupying was hardfought, hard-won, and perpetually contested. "This exhibition, no more or less convincing than any other, no more 'modern' than the one at the Petit Palais, [admittedly] allows us to see Matisse's very beautiful bathers... [and] the restless and agitated compositions of Kandinsky". André Lhote's criticism seems particularly churlishly because he had no personal reason to complain: thirty-four of his paintings hung to acclaim in a dedicated room in the Maitres de l'art indépendant, the much larger and more prestigious show. Lhote's remarks were not just ungenerous but, in retrospect, prematurely confident. The Ville de Paris made a number of acquisitions in 1937 from its show at the Petit Palais, destined for the future Musée d'Art moderne at the Palais de Tokyo, purchases that were to afford the exhibition an enduring significance (Amidon, 1997: 103), but despite the institutionalisation of their works, exceptionally few of these artists have retained their titles as modern "masters" in the scheme of history ${ }^{10}$. To the contrary, and though it still pales in comparison to the amplitude of Barr's Cubism and Abstract Art in New York, the display at the Jeu de Paume, which sought to represent the origins and development of international contemporary art through a succession of movements, assumed a more convincingly modern perspective than its Parisian counterpart, even as it remained unquestionably French in outlook. As Lhote unwittingly noted, the Origines et développement de l'art international indépendant was also the first and only instance that Kandinsky appeared before the French public in a national museum during his lifetime, a feat all the more poignant as it came at the very moment the National Socialists were denouncing his "abominable painting" on the walls of Munich's Entartete Kunst, an unhappy twist of historical fate that surely tempered the artist's lingering disappointment. He had fought for, and won, an official place for his art in the French capital; if certain faults in the composition and execution of the overall display might have been avoided, Kandinsky nevertheless assured Dezarrois that the result was "marvellous" (31 July 1937). Having begun this essay with their initial correspondence, I will conclude by citing Dezarrois's final reply to Kandinsky on the subject, words of mutual consolation as the director reflected upon the artistic mêlée into which he had reluctantly been drawn:

Before the storms whipped up by an exclusivism that I was the first to deplore, having predicted the reaction among those "rejected", I am touched by the testament of your satisfaction and by the flattering assessment you want to make of this difficult and fatally imperfect manifestation. It has at least the distinction of prevailing, the first of its kind in a State Museum; the success it enjoys will better acquaint the cultivated public with the names and the work of the artists thus honoured. (Dezarrois, [Letter], 5 August 1937, 9200.209) 


\section{Referências}

AMIDON, C. "Indépendants" et "Modernisme démodé": Les expositions à Paris en 1937. In: TUROWSKI, A. (ed.). Arts et artistes autour de C. Zervos, Les Fragments... (1). Dijon: Éditions Universitaires de Dijon 1997, p. 99-119.

AMIDON, C. La politique artistique Française des années trente: Étude des expositions en France et à l'étranger. Diss. Université de Paris I, Panthéon-Sorbonne, 1992.

ARNOUX, M. Les Musées français et la peinture allemande: 1871-1981. Paris: Maison des Sciences de l'Homme, 2007.

BARR, A. H. Cubism and Abstract Art. New York: Museum of Modern Art, 1936.

BARR, A. H. [Letter] 27 April 1937, New York [to] DIRECTEUR GÉNÉRAL DES BEAUXARTS [Georges Huisman], Paris. F/21/4731. Sous-série: Beaux-Arts. Archives Nationales, Paris.

COGNIAT, R. L'Art International indépendant. Gazette des Beaux-Arts, Paris, 7 August 1937.

COMMITTEE FOR THE EXHIBITION [Marie Cuttoli, Henri Laugier, Henri Matisse, Fernand Léger, Pablo Picasso, Georges Braque, Louis Marcoussis, Christian Zervos, André Dezarrois] [Letter] 13 July 1937, Paris [to] DIRECTEUR DES MUSÉES NATIONAUX [Henri Verne], Paris. 20150042/50. Direction des musées de France. Archives Nationales, Paris.

CONE, M. C. French Art in Hitler's Berlin. The Art Bulletin, v. 80, n. 3, 2008, p. 555-567.

DEROUET, C. Kandinsky et les Cahiers d'Art (1927-1944). In: CENTRE GEORGES POMPIDOU. Kandinsky: exhibition catalogue. Paris, 2009, p. 306-323.

DEROUET, C. Kandinsky, triumvir de l'exposition du Jeu de Paume en 1937. In: CENTRE GEORGES POMPIDOU. Paris 1937Paris 1957: Créations en France: exhibition catalogue. Paris, 2009, p. 64-67.

DEROUET, C. (ed). Vassily Kandinsky. Correspondances avec Zervos et Kojève. In: Les Cahiers du musée national d'art moderne, hors-série/archives. Paris: Centre Georges Pompidou, 1992.
DEZARROIS, A. [Letter], 24 January 1937, Paris [to] DIRECTEUR GÉNÉRAL DES BEAUX-ARTS [Georges Huisman], Paris. F/21/4473. Sous-série: Beaux-Arts. Archives Nationales, Paris.

DEZARROIS, A. [Letter], 24 February 1937, Paris [to] DIRECTEUR GÉNÉRAL DES BEAUX-ARTS [Georges Huisman], Paris. F/21/4473. Sous-série: Beaux-Arts. Archives Nationales, Paris.

DEZARROIS, A. [Letter] 6 April 1936, Paris [to] DIRECTEUR GÉNÉRAL DES BEAUX-ARTS [Georges Huisman]. 6 April 1936. F/21/4473. Sous-série: Beaux-Arts. Archives Nationales.

DEZARROIS, A. [Letter] 15 July 1937, Paris [to] MATISSE, H., Paris. 20144707/95. Direction des musées de France. Archives Nationales, Paris.

DEZARROIS, A. [Letter] 15 July 1937, Paris [to] SEVERINI, G., Paris. 20144707/95. Direction des musées de France. Archives Nationales, Paris.

DEZARROIS, A. [Letter] 5 August 1937, Paris [to] KANDINSKY, W., Neuilly. 9200.209. Fonds Kandinsky. Bibliothèque Kandinsky, Centre de documentation et de recherche du MNAM, Centre Georges Pompidou, Paris.

DEZARROIS, A. [Letter], 12 September 1937, Paris [to] DIRECTEUR DES MUSÉES NATIONAUX [Henri Verne], Paris. 20150042/50. Direction des musées de France. Archives Nationales, Paris.

En marge de l'Exposition du Jeu de Paume: une lettre ouverte au Président du Conseil. In: Gazette des Beaux-Arts, Paris, 20 August 1937.

GUÉGEN, P. [Letter] 9 July 1937, Paris [to] DEZARROIS, A., Paris. 20144707/95. Direction des musées de France. Archives Nationales, Paris.

HERBIN, A. [Letter] 7 August 1937, Paris [to] DIRECTEUR GÉNÉRAL DES BEAUX-ARTS [Georges Huisman], Paris. F/21/4082. Soussérie: Beaux-Arts. Archives Nationales, Paris. 
KANDINSKY, N. Kandinsky et moi. Paris: Flammarion, 1978.

KANDINSKY, W. Abstract Painting [1936]. In: LINDSAY, K. C.; VARGO, P. (eds). Kandinsky: Complete Writings on Art. New York: Da Capo Press, 1994, p.784-789.

KANDINSKY, W. [Letter] 22 June 1936, Neuilly-sur-Seine [to] BARR, A. H., New York. 9200.246. Fonds Kandinsky. Bibliothèque Kandinsky, Centre de documentation et de recherche du MNAM, Centre Georges Pompidou, Paris.

KANDINSKY, W. [Letter] 21 April 1937, Neuillysur-Seine [to] DEZARROIS, A., Paris. 9200.1511. Fonds Kandinsky. Bibliothèque Kandinsky, Centre de documentation et de recherche du MNAM, Centre George Pompidou, Paris.

KANDINSKY, W. [Letter] 10 May 1937, Neuillysur-Seine [to] DEZARROIS, A., Paris. 9200.1512. Fonds Kandinsky. Bibliothèque Kandinsky, Centre de documentation et de recherche du MNAM, Centre George Pompidou, Paris.

KANDINSKY, W. [Letter] 1 June 1937, Neuillysur-Seine [to] ZERVOS, C., Paris. 9200.1540. Fonds Kandinsky. Bibliothèque Kandinsky, Centre de documentation et de recherche du MNAM, Centre George Pompidou, Paris.

KANDINSKY, W. [Letter] 2 June 1937, Neuillysur-Seine [to] ZERVOS, C., Paris. 9200.1541. Fonds Kandinsky. Bibliothèque Kandinsky, Centre de documentation et de recherche du MNAM, Centre George Pompidou, Paris.

KANDINSKY, W. [Letter] 15 July 1937, Neuillysur-Seine [to] DEZARROIS, A., Paris. 20144707/95. Direction des musées de France. Archives Nationales, Paris.

KANDINSKY, W. [Letter] 31 July 1937, Neuillysur-Seine [to] DEZARROIS, A., Paris. 9200.1514b. Fonds Kandinsky. Bibliothèque Kandinsky, Centre de documentation et de recherche du MNAM, Centre George Pompidou, Paris.

KANGASLAHTI, K. Foreign Artists and the École de Paris: Critical and Institutional
Ambivalence Between the Wars. In: Adamson, $\mathrm{N}$; Norris, T. (eds). Academics, Pompiers, Official Artists and the Arrière-garde: Defining Modern and Traditional in France, 1900-1960. Newcastle: Cambridge Scholars Publishing, 2009, p. 85-112.

Les Expositions. Cahiers d'art, v. 12, n. 4/5, 1937, p. 162-164.

LHOTE, A. Origines et développement de l'Art international indépendant. In: La Nouvelle revue française, v. 25, n. 288, August 1937, p.515-517.

MINISTRE DES AFFAIRES ÉTRANGĖRES [Yvon Delbos] [Letter], 31 December 1935, Paris [to] MINISTRE DE L'ÉDUCATION NATIONALE ET DES BEAUX-ARTS [Jean Zay], Paris. F/21/4731. Sous-série: BeauxArts. Archives Nationales, Paris.

MUSÉE D'ART MODERNE DE LA VILLE DE PARIS. Paris 1937: L'Art indépendant: catalogue. Paris, 1987.

MUSÉE DU JEU DE PAUME. Origines et développement de l'art international indépendant: catalogue. Paris, 1937.

NOYES PLATT, S. Modernism, Formalism, and Politics: The 'Cubism and Abstract Art' Exhibition of 1936 at the Museum of Modern Art. Art Journal, v. 47, n. 4, 1988, p.284-295.

PASSINI, M. Historical Narratives of the Nation and the Internationalization of Museums: Exhibiting National Art Histories in the Jeu de Paume Museum between the Wars. In: POULOT, D.; BODENSTEIN, F.; LANZAROTE GUIRAL, J. M. (eds). Great Narratives of the Past. Traditions and Revisions in National Museums. EuNaMus Report 4. Linköping: University Electronic Press, 2014, p.457-466.

PETIT PALAIS. Maitres de l'art indépendant: catalogue. Paris: Arts et métiers graphiques, 1937.

WEBER, N. F.; BOISSEL, J. (ed.). Josef Albers and Wassily Kandinsky: Friends in Exile. A Decade of Correspondence, 1929-1940. New York: Hudson Hills Press, 2010. 


\section{Notas}

\footnotetext{
* Research Fellow and Visiting Professor, research group Cultural History Since 1750, Department of History, KU Lueven, Belgium (kate.kangaslahti@kuleuven.be)

1 The Maîtres de l'art indépendant (1895-1937), May-October 1937, organised by the curator of the Petit Palais, Raymond Escholier, presented more than 1500 works by the French luminaries of modern art and a select group of foreign-born masters long resident in Paris.

2 Nina Kandinsky's embellished recollections of events are not entirely reliable. She narrates an improbable conversation between her husband and Dezarrois, mistakenly asserting that the Jeu de Paume was due to exhibit modern works from the Guggenheim collection; the Museum of Modern Art was coordinating plans for the retrospective exhibition of American Art scheduled for the summer (Kandinsky, 1978: 208-209).

${ }^{3}$ Dezarrois had seen the painting in December 1936 at a small show of Kandinsky's work at the galerie Jeanne Bucher-Myrbor, which was where, according to Nina Kandinsky (1978: 208) the artist and director first met, paving the way for their later dealings.

${ }^{4}$ Kandinsky had known Zervos since 1927, when the editor first travelled to meet the artist in Dessau. The two had maintained a cordial and mutually beneficial relationship over the years, during which time Zervos assisted Kandinsky with small exhibitions in Paris and published Will Grohmann's first monograph of the painter's work, while Kandinsky contributed to Cahiers d'Art. Their relationship began to deteriorate, however, once Kandinsky moved to Paris at the end of 1933 (Derouet, 2009: 306-323).

${ }^{5}$ This may be explained by the fact that the work was probably in the Jeu de Paume's collection, having been donated to the French State by the artist in 1934, however a painting by the Dutchman Kees van Dongen, who exhibited at the 1905 Salon d'Automne, would have been a more natural choice.

${ }^{6}$ Kandinsky stipulated the following order, with a minimum of 40 centimetres space between each work: Entre deux, Courbe dominante, Développement en brun, L'Arc noir, and Sur blanc.

7 It is not clear why Guégen nominated Breton as the first triumvir as it was Paul Eluard who was on the organising committee and he and Breton were not always on the most cordial of terms at the time (this may also explain Breton's willingness to issue such a public complaint). It is Eluard's name, not Breton's, that appears in the archival documents, as do occasionally the names of Salvador and Gala Dalí and Max Ernst.

8 The abstract painter Alberto Magnelli, who had originally approached Dezarrois alongside Kandinsky and also who lent two of his own works, was the only other Italian artist to feature in the display.

9 Thèse, Antithèse, Synthèse, a small exhibition of Paris-based artists mounted at the Kunstmuseum in Luzern in 1935 by curator Paul Hilber and the Swiss artist Hans Erni, notably grouped together Cubism, Surrealism and abstract art.

${ }^{10}$ The lingering influence of the Maitres de l'art indépendant on the city's collections was evident when the Musée d'Art Moderne de la Ville de Paris partially restaged the show in 1987 as Paris 1937: L'Art indépendant.
}

Artigo recebido em janeiro de 2018. Aprovado em abril de 2018. 